\title{
Peripheral Blood Intracellular Cytokine Analysis in Children Newly Diagnosed with Inflammatory Bowel Disease
}

\author{
DAVID R. MACK, SUSAN BEEDLE, JAIME WARREN, JACK DAVIS, AND THOMAS GROSS \\ Department of Paediatrics, Children's Hospital of Eastern Ontario and University of Ottawa, Ottawa, \\ Ontario, Canada, K1H 8 L1 [D.R.M.]; Department of Pediatrics [D.R.M., J.W.], and \\ Microbiology/Pathology [J.D.], University of Nebraska Medical Center, Omaha, Nebraska 68198, U.S.A.; \\ and Children's Hospital [D.R.M., S.B.], Omaha, Nebraska 68114, U.S.A.; and Department of \\ Hematology/Oncology, Cincinnati Children's Hospital Medical Center, \\ Cincinnati, Ohio 45229, U.S.A. [T.G.]
}

\begin{abstract}
Patterns of cytokine profiles have emerged for different forms of inflammatory bowel disease with a predominance of type 1 cytokines in patients with Crohn disease and type 2 cytokine expression in patients with ulcerative colitis. Most of these studies have involved older patients with long-standing disease or after various therapeutic interventions, and patterns of cytokine expression were hypothesized to be influenced by these factors. To evaluate for these possibilities, we studied 23 patients (15 boys) with newly diagnosed Crohn disease $(n=14)$ or ulcerative colitis. Their mean age at diagnosis was $13.1 \pm 2.9 \mathrm{y}$ (mean $\pm \mathrm{SD})$. Healthy control subjects $(n=9)$ were previously obtained. Peripheral blood intracellular cytokine analysis was performed within $24 \mathrm{~h}$ using a modification of Becton Dickinson's FastImmune Cytokine system. Multiparametric flow cytometry and phenotyping of lymphocytes was performed. T-cell populations were defined as type 1 being $\mathrm{CD}^{+} 9^{+}, \mathrm{CD}^{+}$, and interferon- $\gamma^{+}$and type 2 being $\mathrm{CD}_{6} 9^{+}, \mathrm{CD}^{+}$, and $\mathrm{IL}-4^{+}$. The median percent of type $1 \mathrm{~T}$ cells from normal subjects $(2.8 \%)$ was similar to that of ulcerative colitis subjects $(1.8 \%, p>0.20)$ but greater than that of Crohn disease subjects $(0.55 \%, p=0.05)$. The median percent of type 2 lymphocytes in normal subjects
\end{abstract}

\section{ABSTRACT}

(1.8\%) was greater than that of ulcerative colitis subjects $(0.35 \%$, $p=0.02)$ but was similar to that of Crohn disease subjects $(1.1 \%, p>0.20)$. Serial determinations showed the median percent of type $2 \mathrm{~T}$ cells increased in ulcerative colitis patients as remission was induced. Reduced activated peripheral type $1 \mathrm{~T}$ cells of newly diagnosed, untreated children are similar to interferon- $\gamma$ expression in mucosa of adults with postoperative recurrence. Reduced type 2 cytokine expression patterns in subjects with ulcerative colitis are similar to lamina propria T-cell expression levels in adults and improve with disease remission.

(Pediatr Res 51: 328-332, 2002)

CD, Crohn disease
UC, ulcerative colitis
Th, T helper
IFN- $\gamma$, interferon- $\gamma$
IBD, inflammatory bowel disease
PCDAI, pediatric Crohn disease activity index
FACS, fluorescence-activated cell sorter

It is generally accepted that there exists functionally polarized $\mathrm{CD}^{+}$class II MHC-restricted Th cell responses that develop under the influence of both environmental and genetic factors $(1,2)$. The classification is based on cytokine expression in which Th1-like cells are $\mathrm{CD}^{+}{ }^{+} \mathrm{T}$ cells that produce IFN- $\gamma$ but not IL-4, and Th2 or Th2-like cells are CD4 ${ }^{+}$T cells that express IL-4 but not IFN- $\gamma(1)$. The cytokines produced by Th1 cells are involved with cell-mediated immunity and

Received March 29, 2001; accepted September 17, 2001.

Correspondence and reprint requests: David R. Mack, M.D., Department of Paediatrics, Children's Hospital of Eastern Ontario, 401 Smyth Road, Ottawa, Ontario, K1H 8L1, Canada; e-mail: dmack@cheo.on.ca

Supported by a grant from John A Weibe, Jr. Healthcare Research and Education Fund. phagocyte-dependent protective responses whereas Th2 cytokine expression facilitates antibody production, eosinophil activation, and phagocyte-independent protective responses (1). In addition to normal protective responses, aberrant responses of Th1 and Th2 cells are involved in the pathogenesis of a number of diseases including IBD (3). For instance, Th1 cytokine expression predominance in patients with $\mathrm{CD}$ has been reported (4-6) whereas increased Th2 cytokine expression profiles have been shown in UC (6-8).

Most of the studies have involved adult patients with longstanding or previously treated disease, both factors that might influence cytokine profiles. For instance, cytokine expression profiles for $\mathrm{CD}$ have been reported to be altered during differ- 
ent stages of $\mathrm{CD}$, such as after resection (9). In addition, children can differ from adults in their ability to produce cytokines (e.g. IL-2, IFN- $\gamma$, IL-4) even after maximal stimulation (10). Thus in this study, we sought to evaluate cytokine profiles in circulating $\mathrm{T}$ lymphocytes from children newly diagnosed with IBD before the initiation of therapy to determine whether the cytokine profiles in this group of patients differed from adult reports.

\section{METHODS}

Patients. Twenty-seven consecutive patients were enrolled in the study of which samples from 23 subjects were available for study. The mean $( \pm \mathrm{SD})$ age of the subjects studied was $13.1 \pm 2.9 \mathrm{y}$, with a range in ages from 7.1 to $18.7 \mathrm{y}$. Among the subjects, there were 14 diagnosed with $\mathrm{CD}$ and nine with UC. Diagnosis was established by using the usual clinical, radiologic, endoscopic, and histologic criteria with sites of involvement determined either by endoscopic visualization or barium examination of the jejunum and ileum in $\mathrm{CD}$ subjects. As shown in Table 1, most UC patients had pancolitis at the time of diagnosis, as is common in children (11). Most of the children diagnosed with $\mathrm{CD}$ had colonic or ileocolonic involvement. The mean time of onset of symptoms to time of diagnosis was approximately 14 mo for subjects with $\mathrm{CD}$ and 5 mo for subjects with $\mathrm{UC}(p=0.18)$. The mean $( \pm \mathrm{SD})$ PCDAI score at the time of diagnosis was $38.4 \pm 14.2$ points, and a subject with a PCDAI score $\leq 10$ was considered to have inactive disease in this study $(12,13)$.
Patient specimens. After informed consent or assent was obtained from the subjects and their parents or guardians, peripheral blood $(5-10 \mathrm{~mL})$ was obtained in a heparinized tube for analysis from subjects at the time of diagnosis before the initiation of therapy and during clinical remission. Samples with any clot formation were discarded. Volunteer normal control samples were from adult patients and had been collected before the current study according to Institutional Review Board guidelines established at the University of Nebraska Medical Center. Approval for the study was obtained from the Institutional Review Board of Children's Hospital (Omaha, NE, U.S.A.) and from The Institutional Review Board for the Protection of Human Subjects at the University of Nebraska Medical Center.

Detection of intracellular cytokines. Blood specimens were analyzed as previously described (14) using a modification of Becton Dickinson's FastImmune Cytokine Application Note 1 (Becton Dickinson Immunocytometry Systems, San Jose, CA, U.S.A.) within $24 \mathrm{~h}$ of collection. Briefly, cells were washed in PBS and resuspended at $2 \times 10^{6} / \mathrm{mL}$ in RPMI $1640+2 \mathrm{mM}$ L-glutamine, but without serum. Activation was performed in the presence of phorbol 12-myristate 13-acetate $(25 \mathrm{ng} / \mathrm{mL})$, ionomycin $(1 \mathrm{mg} / \mathrm{mL})$, and brefeldin $\mathrm{A}(10 \mathrm{mg} / \mathrm{mL})$ in $37^{\circ} \mathrm{C}$, $5 \%$ carbon dioxide for $4-5 \mathrm{~h}$ (Becton Dickinson). After incubation, staining for surface antigen-specific fluorescentconjugated MAb CD3 perCP and CD69-FITC was performed. Next, a FACS lysing solution was added to fix external epitopes and assist in permeabilization. After permeabilization

Table 1. Details of patients

\begin{tabular}{|c|c|c|c|c|c|c|c|}
\hline $\begin{array}{c}\text { IBD } \\
\text { subtype }\end{array}$ & Subject & Sex & $\begin{array}{c}\text { Age at } \\
\text { diagnosis }\end{array}$ & $\begin{array}{l}\text { Time of } \\
\text { symptoms to } \\
\text { diagnosis } \\
\text { (mo) }\end{array}$ & Disease location & $\begin{array}{l}\text { PCDAI at } \\
\text { diagnosis }\end{array}$ & Drugs \\
\hline \multirow{14}{*}{$\begin{array}{l}\text { Crohn } \\
\text { disease }\end{array}$} & 1 & M & $12 \mathrm{y}, 3 \mathrm{mo}$ & 24 & Stomach + colon & 35.0 & $\mathrm{P}, \mathrm{M}$ \\
\hline & 2 & M & $9 \mathrm{y}, 11 \mathrm{mo}$ & 1 & Colon alone & 12.5 & $\mathrm{M}, \mathrm{E}, \mathrm{P}, \mathrm{S}, \mathrm{MTX}$ \\
\hline & 3 & M & $12 \mathrm{y}, 7 \mathrm{mo}$ & 6 & Stomach + colon & 42.5 & $\mathrm{P}, \mathrm{A}$ \\
\hline & 4 & M & $13 \mathrm{y}, 2 \mathrm{mo}$ & 1 & Colon alone & 20.0 & $\mathrm{~A}, \mathrm{E}$ \\
\hline & 5 & $\mathrm{M}$ & $11 \mathrm{y}, 11 \mathrm{mo}$ & 3 & Colon alone & 32.5 & $\mathrm{~A}, \mathrm{E}$ \\
\hline & 6 & M & 7 y, $1 \mathrm{mo}$ & 2 & Colon alone & 42.5 & $\mathrm{~S}, \mathrm{~F}, \mathrm{P}$ \\
\hline & 7 & $\mathrm{~F}$ & $14 \mathrm{y}, 7 \mathrm{mo}$ & 48 & TI alone & 60.0 & $\mathrm{P}, \mathrm{I}, \mathrm{F}, \mathrm{M}, \mathrm{MTX}$ \\
\hline & 8 & $\mathrm{~F}$ & $11 \mathrm{y}, 0 \mathrm{mo}$ & 24 & $\mathrm{TI}+$ any colon & 40.0 & $\mathrm{M}, \mathrm{P}, \mathrm{I}$ \\
\hline & 9 & $\mathrm{~F}$ & $17 \mathrm{y}, 0 \mathrm{mo}$ & 2 & $\mathrm{TI}+$ any colon & 37.5 & M, I \\
\hline & 10 & M & $13 \mathrm{y}, 1 \mathrm{mo}$ & 9 & $\mathrm{TI}+$ any colon & 50.0 & $\mathrm{P}, \mathrm{I}, \mathrm{M}$ \\
\hline & 11 & M & 13 y, 4 mo & 12 & TI alone & 42.5 & $\mathrm{P}, \mathrm{I}, \mathrm{M}$ \\
\hline & 12 & $\mathrm{~F}$ & $16 \mathrm{y}, 10 \mathrm{mo}$ & 60 & $\mathrm{TI}+$ any colon & 25.0 & M \\
\hline & 13 & M & 17 y, 2 mo & 1 & Colon alone & 37.5 & $\mathrm{M}, \mathrm{P}, \mathrm{E}, \mathrm{I}$ \\
\hline & 14 & $\mathrm{~F}$ & $18 \mathrm{y}, 8 \mathrm{mo}$ & 5 & Colon alone & 62.5 & $\mathrm{P}, \mathrm{I}, \mathrm{M}$ \\
\hline \multirow{9}{*}{$\begin{array}{c}\text { Ulcerative } \\
\text { colitis }\end{array}$} & 15 & M & $13 \mathrm{y}, 6 \mathrm{mo}$ & 1 & Pancolitis & & $\mathrm{P}, \mathrm{M}$ \\
\hline & 16 & M & $13 \mathrm{y}, 9 \mathrm{mo}$ & 3 & Pancolitis & & $\mathrm{P}, \mathrm{M}, \mathrm{S}, \mathrm{E}, \mathrm{I}$ \\
\hline & 17 & $\mathrm{~F}$ & $15 \mathrm{y}, 11 \mathrm{mo}$ & 4 & Left-sided colitis & & E, M, P, I \\
\hline & 18 & M & $13 \mathrm{y}, 5 \mathrm{mo}$ & 1.5 & Pancolitis & & $\mathrm{P}, \mathrm{I}$ \\
\hline & 19 & M & $9 \mathrm{y}, 11 \mathrm{mo}$ & 1.5 & Pancolitis & & M, P, I \\
\hline & 20 & $\mathrm{~F}$ & $9 \mathrm{y}, 0 \mathrm{mo}$ & 2 & Pancolitis & & $\mathrm{P}, \mathrm{M}, \mathrm{E}, \mathrm{F}$ \\
\hline & 21 & M & $9 \mathrm{y}, 9 \mathrm{mo}$ & 5 & Pancolitis & & M \\
\hline & 22 & M & $13 \mathrm{y}, 3 \mathrm{mo}$ & 24 & Pancolitis & & $\mathrm{M}$ \\
\hline & 23 & $\mathrm{~F}$ & $14 \mathrm{y}, 6 \mathrm{mo}$ & 3 & Pancolitis & & $\mathrm{P}, \mathrm{M}$ \\
\hline
\end{tabular}

Abbreviations used: M, male; F, female; TI, terminal ileum; Drugs used to induce or prescribed at time of remission (Drugs): P, prednisone; M, mesalamine; S, sulphasalazine; E, mesalamine enema; F, metronidazole; I, 6-mercaptopurine/azathioprine; MTX, methotrexate. 
with the FACS permeabilizing solution, labeling with cytokine-specific fluorescent-conjugated intracellular MAb FastImmune anti-Hu IL-4 PE and FastImmune anti-Hu IFN- $\gamma$ PE was performed. An antibody control was performed for each marker. After antibody labeling, cells were fixed in 1\% paraformaldehyde. Samples were stored at $4^{\circ} \mathrm{C}$ in the dark for $\leq 24$ $\mathrm{h}$ before FACS analysis. T-cell populations were defined as type 1 being $\mathrm{CD} 69^{+}, \mathrm{CD}^{+}$, and $\mathrm{IFN}-\gamma^{+}$and type 2 being $\mathrm{CD} 9^{+}, \mathrm{CD}^{+}$, and $\mathrm{IL}-4^{+}$.

Flow cytometry. Multiparametric flow cytometric phenotyping of lymphocytes were performed by standard techniques $(15,16)$. All samples were analyzed on a Coulter Elite flow cytometer equipped with a $400-\mathrm{mW}$ argon ion laser. Fluorescence data were analyzed using Coulter Elite software and three-color analysis protocols. Cells were gated by light scatter and fluorescence for measurements of expression. Background controls consist of isotype, fluorochrome-conjugated matched antibodies and are included for all antibody combinations.

Statistical methods. Median values of type 1 and type $2 \mathrm{~T}$ cells were calculated for normal volunteer controls and subjects with $\mathrm{CD}$ or UC. Median values were compared using Mann-Whitney $U$ test. Statistical analysis and calculations were performed using Statview SE+Graphics, v1.02 (Abacus Concepts, Inc., Berkeley, CA, U.S.A.).

\section{RESULTS}

Quantification of peripheral blood T cells at diagnosis. At the time of diagnosis before the initiation of therapy, children with newly diagnosed $\mathrm{CD}$ had fewer type $1 \mathrm{~T}$ cells (median, $0.55 \%$ ) than did normal control subjects (median, $2.8 \% ; p<$ 0.05 ; Fig. 1). There was no difference in the median percentage of type $1 \mathrm{~T}$ cells between children with new diagnosis of UC (median, 1.8\%) and normal children $(p>0.20)$.

In contrast, children with new-onset UC had fewer peripheral circulating type $2 \mathrm{~T}$ cells (median, $0.35 \%$ ) than did the normal control subjects (median, $1.8 \% ; p=0.05$ ), but newly diagnosed subjects with $\mathrm{CD}$ (median, $1.1 \% ; p>0.20$ ) did not (Fig. 2).

Percentage positive cells are percent cytokine positive of $\mathrm{CD} 9^{+}$and $\mathrm{CD} 3^{+}$cells. $\mathrm{CD} 69^{+}$cells did not have detectable cytokines. The percentage of cells $\mathrm{CD}^{+}, \mathrm{CD}^{+}$and $\mathrm{CD}^{+}$, $\mathrm{CD} 8^{-}$were measured but there was no statistical difference between any of the groups.

Quantification of peripheral blood $T$ cells at remission. Six subjects with UC had T-cell phenotype determinations for both the time of diagnosis and the time of remission. Among UC subjects, remission was determined by clinical resolution of symptomatology, lack of passage of rectal blood, and normalization of blood tests (complete blood cell count, sedimentation rate, albumin). As shown in Figure 3, serial determinations showed that the median percent of type $2 \mathrm{~T}$ cells increased as remission was induced $(p=0.02)$. There was not an increase in median percent type 1 cells in serial determinations among $\mathrm{CD}$ patients from the time of diagnosis $(n=6)$ to remission $(p$ $=0.60$ ). Similarly, comparing other changes in type 1 and type 2 cells from diagnosis to remission did not yield differences.

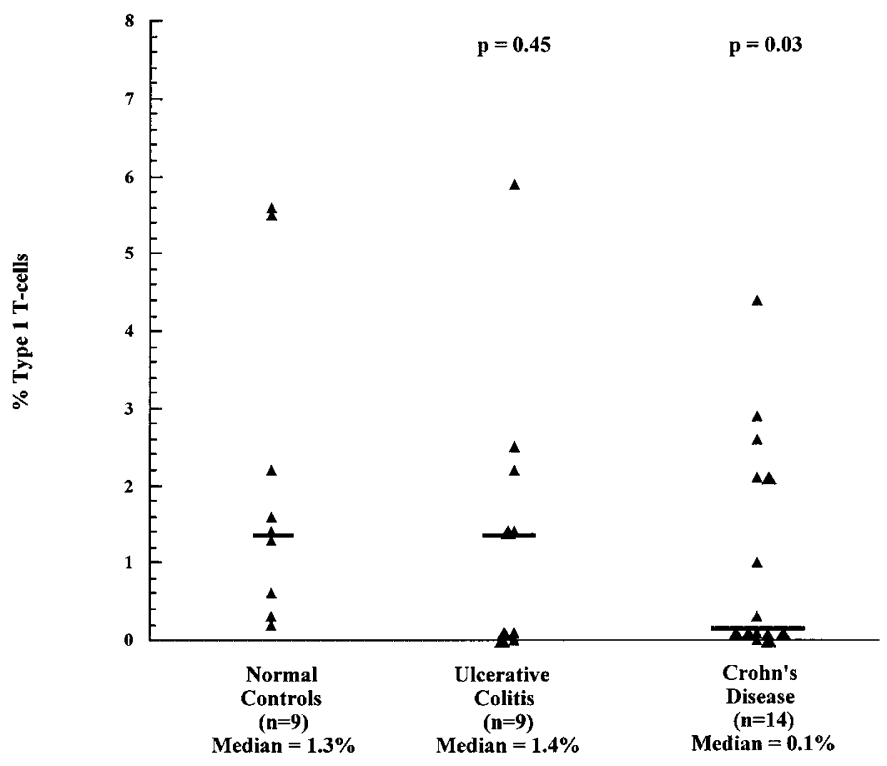

Figure 1. Type $1 \mathrm{~T}$ cells in the peripheral blood in patients at the time of diagnosis. Individual values and medians (horizontal lines) are shown. The number of patients $(n)$ is indicated for the three groups. Comparison of groups with normal control subjects is indicated by $p$ value.

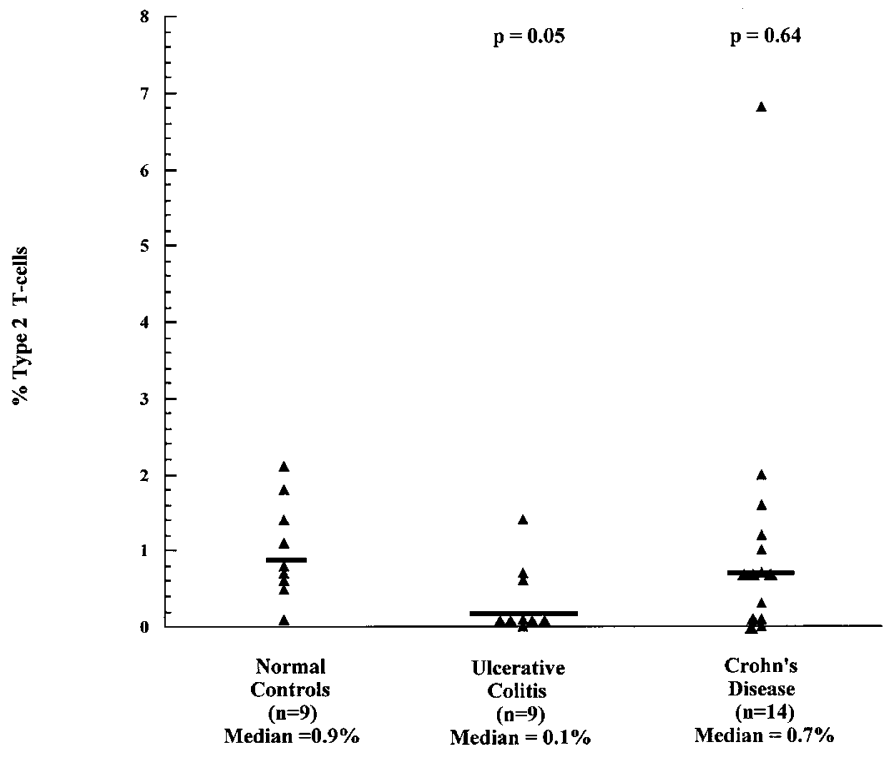

Figure 2. Type $2 \mathrm{~T}$ cells in the peripheral blood in patients at the time of diagnosis. Individual values and medians (horizontal lines) are shown. The number of patients $(n)$ is indicated for the three groups. Comparison of groups to normal control subjects is indicated by $p$ value.

\section{DISCUSSION}

In the present study we show that there is a difference in the $\mathrm{T}$ cells found in the peripheral blood of newly diagnosed children with the two most common subtypes of IBD, namely $\mathrm{CD}$ and UC. In the subjects with $\mathrm{CD}$ there are fewer type 1 $\left(\mathrm{CD} 9^{+}, \mathrm{CD}^{+}, \mathrm{IFN}-\gamma^{+}\right) \mathrm{T}$ cells in the peripheral blood. In contrast, among newly diagnosed children with UC there are fewer type $2\left(\mathrm{CD} 9^{+}, \mathrm{CD} 3^{+}, \mathrm{IL}-4^{+}\right) \mathrm{T}$ cells.

Evaluations of mucosal biopsies from patients with $\mathrm{CD}$ by mRNA profiles (4) and immunohistochemistry (5) have revealed higher IFN- $\gamma$ compared with mucosa from UC patients 


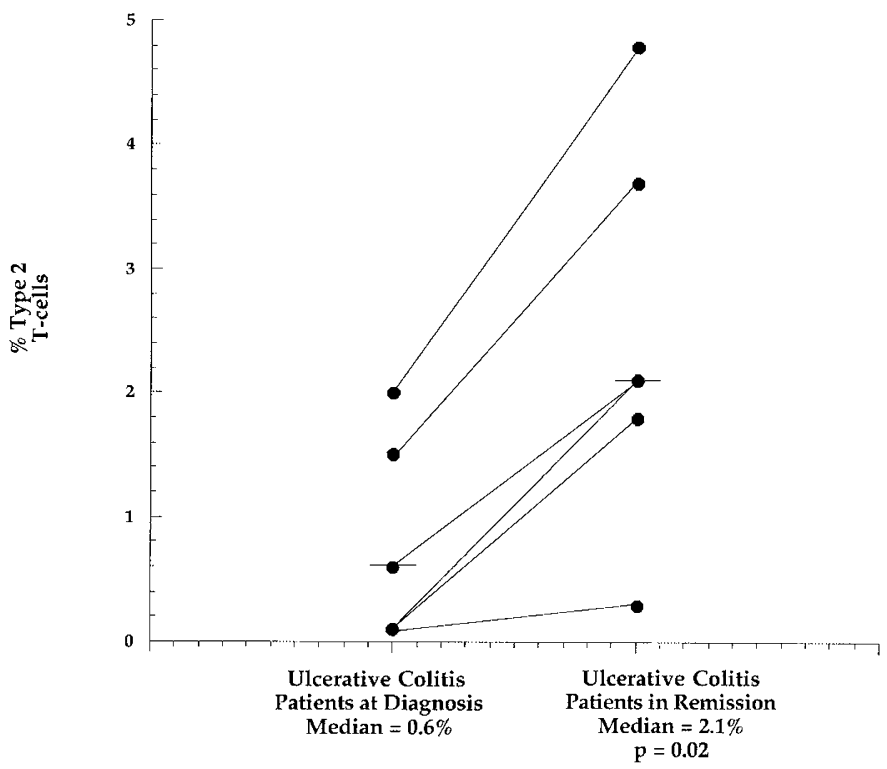

Figure 3. Serial determinations of type $2 \mathrm{~T}$ cells in peripheral blood of $\mathrm{UC}$ subjects. Individual values and medians (horizontal lines) are shown with corresponding values indicated by connecting lines.

and control subjects. These results represent measurement of cytokine from more than lymphocytes (total mRNA of lymphocytes and macrophages). Patient details in the study by Mullin et al. (4) are not given, but in the study of Camoglio et al. (5), the mean duration of disease was greater than $6 \mathrm{y}$ and the mean age of the patient was older than $32 \mathrm{y}$. In a study of surgical resection specimens obtained from adult patients, which evaluated enriched $\mathrm{CD} 4^{+} \mathrm{T}$ cells, IFN- $\gamma$ secretion by both freshly isolated lamina propria and peripheral blood $\mathrm{CD} 4^{+} \mathrm{T}$ cells was found to be increased compared with $\mathrm{CD} 4^{+}$ $\mathrm{T}$ cells from UC patients and control subjects (6). Thus, despite a number of variables to consider in cytokine analysis in IBD patients (17), there is a correlation between lamina propria $\mathrm{CD}^{+}{ }^{+} \mathrm{T}$ cells and peripheral blood $\mathrm{CD}^{+} \mathrm{T}$ cells. In all of these studies most patients were receiving various medications. Of interest to our study on children with newly diagnosed IBD of short duration before the introduction of medications was the report of Desreumaux et al. (9). In their study, biopsy specimens were obtained from patients before a surgical resection and 3 mo after the resection. Reverse transcriptase-PCR analysis was applied to total mRNA isolated from biopsy specimens. Medications were discontinued before the surgery. In biopsy specimens obtained from mucosa with active disease before surgery, IFN- $\gamma$ was higher than in biopsies obtained from mucosa in patients that relapsed postoperatively. The IFN- $\gamma$ signals from mucosa obtained from those patients with postoperative recurrence were lower compared with control subjects and those patients without postoperative recurrence. There are certain analogies between the study of Desreumaux et al. (9) and the current study, which include new onset of disease and subjects without medications.

In UC, total mRNA analysis from biopsy specimens have revealed higher IL-4 expression levels in actively inflamed mucosa compared with noninflamed UC mucosa and that from non-UC inflamed mucosa (8) or showed a trend but no statis- tical difference (4). In other studies of older patients with previously established $\mathrm{CD}$ or UC and taking various medications, decreased production of IL-4 from isolated lamina propria $\mathrm{CD}^{+}{ }^{+} \mathrm{T}$ cells or mononuclear cells compared with control subjects was determined $(6,7)$. The opposing results from these studies may be on the basis that total mRNA detection techniques will detect IL-4 mRNA from cellular sources other than mononuclear cells and mRNA expression does not necessarily correlate with protein expression. In our study, we found the peripheral blood IL-4-producing cells were reduced only in UC patients at diagnosis. In those patients who underwent serial determinations from the time of diagnosis, when no medications had been given, to the time of remission after which various medications had been administered, the median percent of IL-4-producing cells rose. There are no adult cytokine studies of new-onset compared with long-standing UC to compare our results with that are analogous to the new-onset versus long-standing $\mathrm{CD}$ such as that described by Desreumaux et al. (9).

It is apparent that the age group of children evaluated in our study mounts an immunologic cellular response in both subtypes of IBD. Furthermore it is apparent that cytokine expression is not necessarily static. The cytokine alterations we describe in new-onset $C D$ in children before therapy are similar to recurrence of $\mathrm{CD}$ in adults after resection. From this study, we suspect that medications or length of time of mucosal inflammation may be a factor in the intracellular cytokine expression profile. This may be an explanation of why medications such as infliximab are effective in some patients with UC (18) as well as in patients with CD (19). In addition, this may also be an explanation for the finding that other drugs such as cyclosporine with benefit in the acute phases of disease (20) do not have maintenance benefits (21) and why medications such as mercaptopurine become less effective with continued usage (22). As therapy for subtypes of IBD becomes more cytokine specific, it will be interesting to determine whether new-onset disease will respond differently than long-standing disease and which combinations or sequences of therapies should be used.

\section{REFERENCES}

1. Abbas AK, Murphy KM, Sher A 1996 Functional diversity of helper T lymphocytes. Nature 383:787-793

2. Romaganni S 1999 Th1/Th2 cells. Inflamm Bowel Dis 5:285-294

3. Fiocchi C 1998 Inflammatory bowel disease: etiology and pathogenesis. Gastroenterology 115:182-205

4. Mullin GE, Maycon ZR, Braun-Elwert L, Cerchia R, James SP, Katz S, Weissman GS, McKinley MJ, Fisher SE 1996 Inflammatory bowel disease mucosal biopsies have specialized lymphokine mRNA profiles. Inflamm Bowel Dis 2:16-26

5. Camoglio L, Te Velde AA, Tigges AJ, Das PK, Van Deventer SJH 1998 Altered expression of interferon- $\gamma$ and interleukin- 4 in inflammatory bowel disease. Inflamm Bowel Dis 4:285-290

6. Fuss IJ, Neurath M, Boirivant M, Klein JS, de la Motte C, Strong SA, Fiocchi C, Strober W 1996 Disparate CD4 ${ }^{+}$lamina propria (LP) lymphokine secretion profiles in inflammatory bowel disease. J Immunol 157:1261-1270

7. West GA, Matsuura T, Levine AD, Klein JS, Fiocchi C 1996 Interleukin 4 in inflammatory bowel disease and mucosal immune reactivity. Gastroenterology 110:1683-1695

8. Inoue S, Matsumoto T, Iida M, Mizuno M, Kuroki F, Hoshika K, Shimizu M 1999 Characterization of cytokine expression in the rectal mucosa of ulcerative colitis: correlation with disease activity. Am J Gastroenterol 94:2441-2446

9. Desreumaux P, Brandt E, Gambiez L, Emilie D, Geboes K, Klein O, Ectors N, Cortot A, Capron M, Colombel JF 1997 Distinct cytokine patterns in early and chronic ileal lesions of Crohn's disease. Gastroenterology 113:118-126 
10. Lilic D, Cant AJ, Abinun M, Calvert JE, Spickett GP 1997 Cytokine production differs in children and adults. Pediatr Res 42:237-240

11. Hyams J, Davis P, Lerer T, Colletti RB, Bousvaros A, Leichtner A, Benkov K, Justinich C, Markowitz J 1997 Clinical outcome of ulcerative proctitis in children. J Pediatr Gastroenterol Nutr 25:149-152

12. Hyams JS, Ferry GD, Mandel FS, Gryboski JD, Kibort PM, Kirschner BS, Griffiths AM, Katz AJ, Grand RJ, Boyle JT, Michener WM, Levy JS, Lesser ML 1991 Development and validation of a pediatric Crohn's disease activity index. J Pediatr Gastroenterol Nutr 12:439-447

13. Hyams JS, Mandel F, Ferry GD, Gryboski JD, Kibort PM, Kirschner BS, Griffiths AM, Katz AJ, Boyle JT 1992 Relationship of common laboratory parameters to the activity of Crohn's disease in children. J Pediatr Gastroenterol Nutr 14:216-222

14. Ferry B, Antrobus P, Huzicka I, Farrell A, Lane A, Chapel H 1997 Intracellular cytokine expression in whole blood preparations from normals and patients with atopic dermatitis. Clin Exp Immunol 110:410-417

15. Jung T, Schauer U, Heusser C, Neumann C, Rieger C 1993 Detection of intracellular cytokines by flow cytometry. J Immunol Methods 159:197-207

16. Vikingsson A, Pederson K, Muller D 1994 Enumeration of IFN-gamma producing lymphocytes by flow cytometry and correlation with quantitative measurement of IFN-gamma. J Immunol Methods 173:219-228
17. Fiocchi C, Fukushima K, Strong SA, Ina K 1996 Pitfalls in cytokine analysis in inflammatory bowel disease. Aliment Pharmacol Ther 10(suppl 2):63-69

18. Sands BE, Tremaine WJ, Sandborn WJ, Rutgeerts PJ, Hanauer SB, Mayer L, Targan SR, Podolsky DK 2001 Infliximab in the treatment of severe, steroid-refractory ulcerative colitis. Inflamm Bowel Dis 7:83-88

19. Rutgeerts P, D'Haens G, Targan S, Vasiliaukas E, Hanauer SB, Present DH, Mayer L, Van Hogezand RA, Braakman T, DeWoody KL, Schaible TF, Van Deventer SJH 1999 Efficacy and safety of retreatment with anti-tumor necrosis factor antibody (infliximab) to maintain remission in Crohn's disease. Gastroenterology 117:761-769

20. Brynskov J, Freund L, Rasmussen SN, Lauritsen K, Schaffalitzky de Muckadell O, Williams N, MacDonald AS, Tanton R, Molina F, Campianini MC, Bianchi P, Ranzi T, Quarto di Palo F, Malchow-Moller A, Thomsen OO, Tage-Jensen U, Binder V, Riis P 1989 A placebo-controlled, double-blind, randomized trial of cyclosporine therapy in active chronic Crohn's disease. N Engl J Med 321:845-850

21. Feagan BG, McDonald JWD, Rochon J, Laupacis A, Fedorak RN, Kinnear D, Saibil F, Groll A, Archambault A, Gillies R, Valberg B, Irvine EJ 1994 Low-dose cyclosporine for the treatment of Crohn's disease. N Engl J Med 330:1846-1851

22. Bouhnik Y, Lemann M, Mary JY, Scemama G, Tai R, Matuchansky C, Modigliani R, Rambaud C 1996 Long-term follow-up of patients with Crohn's disease treated with azathioprine or 6-mercaptopurine. Lancet 347:215-219 